\title{
Perbaikan Proses Produksi Antosianin dari Kelopak Bunga Rosella dengan Ekstraksi Berbantuan Ultrasound
}

\author{
Meilya Suzan Triyastuti ${ }^{1^{*}}$, Mohamad Djaeni ${ }^{2}$ \\ ${ }^{1}$ Program Studi Teknologi Pengolahan Produk Perikanan, Politeknik Kelautan dan Perikanan Bitung, \\ Jl. Tandurusa Kotak Pos 12/BTG, Bitung, Sulawesi Utara, Indonesia 95526 \\ 2 Departemen Teknik Kimia, Fakultas Teknik, Universitas Diponegoro, \\ Jl. Prof. Soedarto, SH, Kampus UNDIP Tembalang, Semarang, Indonesia 50275
}

\begin{abstract}
Abstrak
Kelopak bunga rosella mengandung senyawa bioaktif diantaranya Antosianin. Kelopak bunga rosella mempunyai pigmen berwarna ungu yang berpotensi sebagai zat pewarna alami untuk menggantikan pewarna sintetis Violet GB. Pigmen warna ungu ini berasal dari senyawa antosianin. Namun senyawa antosianin ini mudah terdegradasi pada temperatur diatas $70^{\circ} \mathrm{C}$, sehingga diperlukan metode ekstraksi yang tepat pada kondisi optimum. Metode yang digunakan yaitu ekstraksi dengan bantuan gelombang ultrasonik (Ultrasound Assisted Extraction) dan dioptimasi menggunakan software Design Expert. Hasil penelitian menunjukkan bahwa kondisi optimum ekstraksi pada waktu ekstraksi 15 menit, rasio sampel dan pelarut $15 \mathrm{gr} / \mathrm{ml}$ dan temperatur ekstraksi $50^{\circ} \mathrm{C}$ dengan kadar antosianin sebesar 206,996 ppm.
\end{abstract}

Kata kunci: Antosianin; Kelopak Bunga Rosella; Ultrasound Assisted Extraction

\begin{abstract}
[Title: Improvement of Production Process of Anthocyanin of Roselle Calyces by Using Ultrasound Assisted Extraction]. Roselle calyces contain bioactive compounds including Anthocyanin. Roselle calyces have purple pigments that is potential to be food colouring to replace Violet GB synthetic food colouring. This purple pigment comes from anthocyanin compounds. However, this anthocyanin compound is easily degraded at temperatures above $70^{\circ} \mathrm{C}$, so that the right extraction method at optimum conditions is needed. The method used is extraction with the help of ultrasonic waves (Ultrasound Assisted Extraction) and optimized using Design Expert software. The results shows that the optimum extraction conditions at 15 minutes extraction time, the ratio of samples and solvents were $15 \mathrm{gr} / \mathrm{ml}$ and extraction temperature was $50^{\circ} \mathrm{C}$ with anthocyanin content 206,996 ppm.
\end{abstract}

Keywords: Anthocyanin; Roselle calyces; Ultrasound Assisted Extraction

\section{Pendahuluan}

Pewarna makanan atau warna aditif merupakan zat warna yang ditambahkan pada makanan, minuman maupun obat-obatan. Warna aditif berasal dari bahan kimia yang bereaksi dengan zat lain sehingga menyebabkan pembentukan warna. Tujuan penggunaan warna aditif dalam makanan diantaranya menstabilkan warna karena paparan cahaya, udara, suhu dan kondisi

\footnotetext{
${ }^{*}$ Penulis Korespondensi.

E-mail: meilyalia92@gmail.com
}

penyimpanan; menciptakan warna alami agar makanan lebih unik dan menarik pada bahan pangan yang tidak berwarna; mempermudah konsumen untuk mengidentifikasi produk pangan khususnya obat obatan (Boer, 2013; Newsome $d k k$., 2014). Pada umumnya, warna sintetis sering digunakan karena harganya murah, umur simpan lama, multifungsi (Chen $d k k$., 2013; Vinha et al. 2018). Namun, penggunaan warna sintetis dapat membentuk senyawa beracun yang menyebabkan gangguan kesehatan maka diperlukan pewarna yang food grade. Pewarna alami dari bahan alam menjadi inovasi pewarna alami yang food grade dan bermanfaat 


\section{TEKNIK, 40 (2), 2019, 116}

bagi kesehatan (Solymosi $d k k$., 2015). Sumber pewarna alami diperoleh dari buah dan sayuran, contohnya warna kuning dari lemon, merah muda dari buah anggur, biru dari blueberry, dan merah dari rosella dan stroberi. Pewarna alami dari buah sangat identik dengan warna dan aroma yang khas (Dai dan Mumper 2010); Manach $d k k ., 2004$; Triyastuti $d k k ., 2017$; Boer 2013).

Hibiscus sabdariffa L. (Malvaceae) yang dikenal dengan rosella merupakan tanaman tropis dan subtropis yang dapat dibudidayakan di Indonesia, India, Saudi Arabia, China, Malaysia (Inggrid $d k k$., 2017). Tanaman rosella mempunyai manfaat yang penting dalam bidang pangan maupun obat tradisional. Keloak rosella kering maupun segar digunakan sebagai bahan colouring dan flavouring pada rum (Piyarat, Walaisiri, \& Pornpen, 2014; Cissé $d k k$., 2012). Farmakologi dari kelopak bunga rosella yaitu asam organik, antosianin, polisakarida dan flavonoid (Hussein $d k k$., 2010). Pigmen kelopak rosella memiliki 3 isolasi antosianin diantaranya delphinidin-3-sambubioside (hibiscin), delphinidin-3glucoside dan cyanidin-3-glucoside (chrysanthenin) (Eiman $d k k ., 2014$ ) yang ditunjukkan pada Gambar 1. Di Eropa, antosianin telah diklasifikasikan sebagai pewarna alami dengan kode E163 (Lee $d k k$., 2005). Antosianin merupakan kelompok senyawa fenolik alami yang menghasilkan warna merah cerah, biru, dan ungu pada buah, sayur dan bunga. Pigmen antosianin mempunyai warna yang menarik, tidak berbahaya dan bermafaat bagi kesehatan (Castañeda-Ovando $d k k$., 2009). Dengan demikian, rosella berpotensi sebagai pewarna alami makanan yang baik bagi kesehatan.

Antosianin mudah terdegradasi pada suhu tinggi. Diperlukan metode ekstraksi yang efektif dan effisien untuk meningkatkan kandungan antosianin Hibiscus Sabdariffa. Metode nonconventional lebih efisien dan proses yang cepat dibandingkan dengan metode ekstraksi konvensional. Teknik Ultrasound-Assisted Extraction (UAE) merupakan salah satu metode nonconventional dalam pengolahan pangan yang efektif, non-thermal atau low temperature dan cepat dibandingkan Microwave-assisted extraction (MAE), Pulsed electric field (PEF) extraction, Supercritical fluid extraction (SPE), Enzyme-assisted extraction $(E A E)$. Namun kekurangan PEF dan SPE adalah harga instrumentasi yang tinggi, EAE adalah harga enzim yang mahal dan MAE adalah senyawa bioaktif mudah terdegradasi. UAE merupakan metode ekstraksi yang tepat untuk menghasilkan kandungan senyawa bioaktif yang tinggi dengan waktu ekstraksi yang lebih pendek (Maran, 2017). Maran (2017) menghasilkan kandungan total antosianin sebesar 10,26 (mg/ $100 \mathrm{~g})$ dari buah Nephelium Lappaceum L. menggunakan UAE dan optimasi central composite face centered response surface design. Yield total antosianin dan phenolic dengan optimasi metode UAE lebih tinggi daripada menggunakan metode Conventional Solvent Extraction (CSE) (He $d k k$., 2016). Pengaruh kavitasi dalam pelarut pada UAE menghasilkan gerakan molekul yang lebih cepat dan penetrasi pelarut yang baik ke dalam bahan ekstraksi (Corbin $d k k$., 2015). Fenomena ini menghasilkan percepatan pelepasan senyawa yang diinginkan (Chavan, Avhad, \& Rathod, 2015). Oleh karena itu, UAE merupakan metode ekstraksi yang efektif dimanfaatkan pada ekstraksi senyawa bioaktif dari sumber alami untuk diaplikasikan pada bidang pangan (Corbin $d k k$., 2015).

Optimasi kondisi ekstraksi sangat penting untuk menghasilkan kadar antosianin yang tinggi. Respon Surface Methodelogy (RSM) merupakan alat matematika dan statistik yang telah banyak digunakan untuk menyelidiki optimasi variabel eksperimental dalam berbagai proses (Bezerra $d k k ., 2008$ ). Tujuan penelitian ini, mendapatkan kadar antosianin optimum dengan memprediksi kondisi optimum UAE, berdasarkan waktu ekstraksi, temperature ekstraksi dan rasio bahan dan pelarut menggunakan Box Bohnken Design.

\section{Bahan dan Metode Bahan}

Kelopak rosella ungu kering diperoleh dari Kediri, Jawa timur. Mereduksi rosella ungu kering berukuran 60 mesh. Menyimpan bubuk kelopak bunga rosella kering (kadar air 12-14\%) pada temperatur ruang, di dalam lemari yang gelap dan kering.

\section{Ultrasound-Assisted Extraction}

Ekstraksi antosianin dari kelopak bunga rosella ungu menggunakan metode UAE (Branson 3510EDTH). UAE merupakan ekstraksi non konvensional yang memanfaatkan bantuan gelombang ultrasonic dengan frekuensi antara $20 \mathrm{kHz}$ hingga $2000 \mathrm{kHz}$. Variabel independen dalam ekstraksi kelopak bunga rosella ungu dengan UAE : suhu ekstraksi $\left(50-60^{\circ} \mathrm{C}\right)$, waktu ekstraksi (15-25 menit) dan Rasio $(15-30 \mathrm{ml} / \mathrm{g})$. Detail variabel independen ditunjukkan pada Tabel 1.

Tabel 1. Nilai dan kode percobaan dari variabel independen menggunakan Box Bohnken Design

\begin{tabular}{llll}
\hline \multirow{2}{*}{$\begin{array}{c}\text { Tingkat } \\
\text { faktor }\end{array}$} & \multicolumn{3}{c}{ Variabel Independen } \\
\cline { 2 - 4 } & Suhu & Rasio Cair- & $\begin{array}{c}\text { Waktu } \\
\text { ekstraksi }\left({ }^{\circ} \mathrm{C}\right)\end{array}$ \\
padat $(\mathrm{mL} / \mathrm{g})$ & ekstraksi \\
\hline-1 & 50 & 15 & 15 \\
0 & 55 & 22,5 & 20 \\
+1 & 60 & 30 & 25 \\
\hline
\end{tabular}

\section{Kadar Total Antosianin}

Analisis kadar total antosianin dari kelopak rosella ungu menggunakan metode perbedaan $\mathrm{pH}$ (Lee 


\section{TEKNIK, 40 (2), 2019, 117}

$d k k ., 2005)$ yang mana dapat diukur menggunakan spektrofotometer (Shimadzu UV-1800, Kyoto, Japan). Metode perbedaan $\mathrm{pH}$ menggunakan buffer pada $\mathrm{pH} 1$ dan $\mathrm{pH}$ 4,5. Pembuatan buffer pada $\mathrm{pH} 1$ menggunakan larutan potassium kloridan dan pelarut air sedangkan pada $\mathrm{pH} 4.5$ menggunakan sodium asetat dan pelarut air dengan penambahan $\mathrm{HCl}$. Mengencerkan ekstrak kelopak bunga rosella sebanyak $0,5 \mathrm{ml}$ dengan menambahkan larutan buffer $\mathrm{pH} 1$ dan $\mathrm{pH} 5$ pada labu ukur $50 \mathrm{ml}$. Penentuan absorbansi sampel ekstrak kelopak bunga rosella ungu $\mathrm{pH} 1$ dan $\mathrm{pH}$ 4,5 pada panjang gelombang $520 \mathrm{~nm}$ dan $700 \mathrm{~nm}$ menggunakan alat spektrofotometer UV-Vis. Berikut ini persamaan menghitung konsentrasi pigmen antosianin ( $\mathrm{He} d k k$., 2016):

Antosianin $(\mathrm{mg} / \mathrm{L})=\frac{\mathrm{A} \times \mathrm{MW} \times \mathrm{DF} \times 10^{3}}{\varepsilon \times 1}$

dimana, $A=\left(\mathrm{A}_{520 \mathrm{~nm}}-\mathrm{A}_{700 \mathrm{~nm}}\right) \mathrm{pH} 1.0-\left(\mathrm{A}_{520 \mathrm{~nm}}-\mathrm{A}_{700 \mathrm{~nm}}\right) \mathrm{pH}$ 4.5; $\mathrm{MW}=449,2 \mathrm{~g} / \mathrm{mol}$ (untuk Cyanidin-3-glucoside); $\mathrm{DF}=$ faktor pengenceran; $1=$ panjang kuvet; dan $\varepsilon=$ 26900 koefisien ekstingsi molar.

Tabel 3. Optimasi Kondisi Ekstraksi Antosianin menggunakan Box Bohnken Design

\begin{tabular}{lccccc}
\hline Run & $\begin{array}{c}\text { Suhu } \\
\left({ }^{\mathbf{C}} \mathbf{C}\right)\end{array}$ & $\begin{array}{c}\text { Waktu } \\
(\text { menit) }\end{array}$ & $\begin{array}{c}\text { Rasio } \\
(\mathbf{m l} / \mathbf{g})\end{array}$ & $\begin{array}{c}\text { Kadar } \\
\text { Antosianin } \\
\text { aktual } \\
\text { (ppm) }\end{array}$ & $\begin{array}{c}\text { Kadar } \\
\text { Antosianin } \\
\text { prediksi } \\
\text { (ppm) }\end{array}$ \\
\hline 1 & 55 & 25 & 30 & 98,69 & 109,99 \\
2 & 60 & 25 & 22,5 & 114,39 & 103,59 \\
3 & 55 & 20 & 22,5 & 105,76 & 105,76 \\
4 & 55 & 20 & 22,5 & 105,76 & 105,76 \\
5 & 55 & 15 & 30 & 65,33 & 58,04 \\
6 & 50 & 20 & 15 & 202,06 & 202,57 \\
7 & 55 & 20 & 22,5 & 105,76 & 105,76 \\
8 & 50 & 25 & 22,5 & 113,97 & 106,17 \\
9 & 60 & 15 & 22,5 & 82,38 & 90,17 \\
10 & 60 & 20 & 15 & 150,01 & 153,51 \\
11 & 50 & 20 & 30 & 52,32 & 48,81 \\
12 & 55 & 15 & 15 & 205,40 & 194,10 \\
13 & 55 & 25 & 15 & 171,44 & 178,73 \\
14 & 55 & 20 & 22,5 & 105,76 & 105,76 \\
15 & 50 & 15 & 22,5 & 72,22 & 83,01 \\
16 & 55 & 20 & 22,5 & 105,76 & 105,76 \\
17 & 60 & 20 & 30 & 102,98 & 102,4651 \\
\hline
\end{tabular}

\section{Desain Percobaan}

Optimasi Box Bohnken Design ditentukan menggunakan software Design-Expert (Version 12, StatEase Inc., USA). Optimasi Box Bohnken Design dengan 3 variabel independen : suhu ekstraksi $\left(50-60^{\circ} \mathrm{C}\right)$, waktu ekstraksi (15-25 menit) dan Rasio (15-30 ml/g). Detail design optimasi ekstraksi antosianin menggunakan Box Bohnken Design ditunjukkan pada tabel 3. Variabel respon (kadar total antosianin) dicocokkan dengan persamaan model polinomial orde kedua pada persamaan 1, yang mampu menggambarkan hubungan antara respon dana variabel independen (He $d k k$., 2016). Berikut ini persamaan model polinomial orde kedua :

$Y=\beta_{0}+\sum_{i=1}^{k} \beta_{i} X_{i}+\sum_{i=1}^{k} \beta_{i i} X_{i i}{ }^{2}+\sum_{i}^{k-1} \sum_{j}^{k} \beta_{i j} X_{i} X_{j}$

dimana, $\mathrm{Y}=$ Variabel Respon (kadar total antosianin); $X_{i}$ dan $X_{j}=$ independen variabel; $\beta_{0}=$ koefisien konstan; $\beta_{i}=$ koefisien linier; $\beta_{i i}=$ koefisien kuadratik; $\operatorname{dan} \beta_{i j}=$ koefisien cross-product .

\section{Hasil dan Pembahasan \\ Ekstraksi Antosianin dari kelopak rosella ungu dengan UAE}

Antosianin merupakan senyawa flavonoid yang memiliki manfaat untuk meningkatkan stabilitas pewarna alami, industri makanan dan kecantikan. Senyawa alami antosianin dari kelopak rosella ungu bermanfaat bagi kesehatan manusia sebagai pencegahan dan pengobatan berbagai patologi. Antosianin merupakan pigmen flavonoid yang larut dalam air yang menghasilkan warna biru, ungu, dan merah dari tanaman (Vinha $d k k .$, 2018). Gambar 1 menunjukkan struktur antosianin. Ekstraksi kelopak rosella ungu dengan metode UAE menggunakan pelarut air distilasi yang bersifat polar sehingga mampu mengekstraksi antosianin, hal ini berdasarkan solute akan larut sempurna dalam pelarut yang nilai polaritasnya sama (Pandey \& Tripathi 2014; Kumoro, 2015).

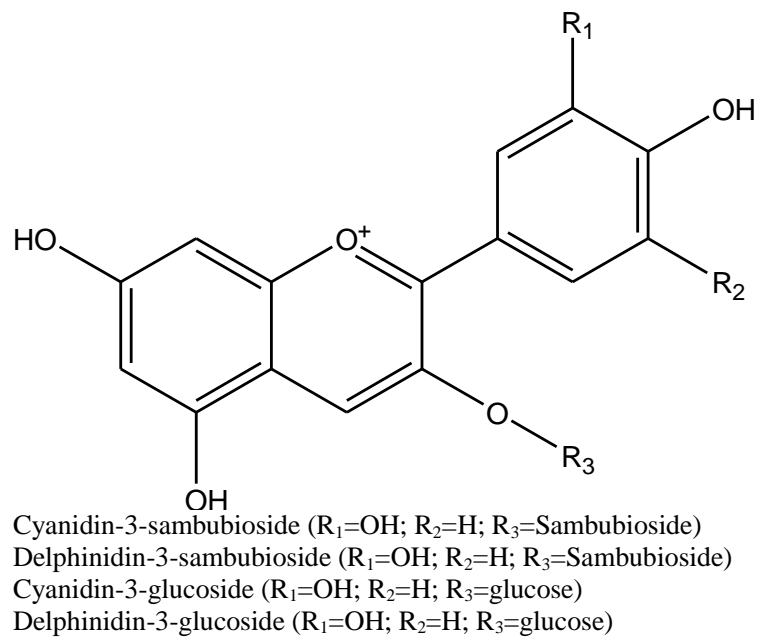

Gambar 1. Struktur Antosianin

Pewarna alami mudah terdegradasi dan tidak stabil selama pemrosesan sehingga diperlukan kondisi 


\section{TEKNIK, 40 (2), 2019, 118}

operasi yang optimum untuk menghasilkan kadar antosianin yang tinggi. Mekanisme degradasi antosianin ditunjukkan pada gambar 2. Menurut Sinela et al. (2017) degradasi antosianin diidentifikasi dengan cara oksidasi yang dikatalisis dengan logam yang mengakibatkan reaksi kondensasi dan secara pemutusan ikatan. Antosianin dioksidasi mennjadi radikal semikuinon dan kuinon sedangkan $\mathrm{O}_{2}$ direduksi menjadi hidrogen peroksida, dan seluruh dimediasi oleh siklus redoks $\mathrm{Fe}^{3+}, \mathrm{Cu}^{2+}, \mathrm{Mn}^{2+}$ (Elias dkk., 2009). Kuinon dapat bergabung dengan senyawa nukleofilik (karbohidrat, asama amino, fenol, dll) karena mempunya sifat elektrofiliknya yang tinggi ( $\mathrm{Li} d k k ., 2008$ ). Penggabungan kuinon dan senyawa nukleofilik dapat menghasilkan polimer yang mempunyai potensi redoks lebih rendah daripada fenol awal dan lebih mudah teroksidiasi. Oleh karena itu, oksidasi produk ini menghasilkan proses polimerisasi yang lebih cepat. Degradasi termal delphinidin lebih cepat dibandingkan sianidin karena terkait peningkatan oksidasi yang berpengaruh pada peningkatan jumlah fungsi hidroksil pada cincin B. Degradasi oksidatif cincin B fenolik merupakan reaksi degradasi yang dominan pada suhu tinggi $\left(20^{\circ} \mathrm{C}\right)$ (Hrazdina $\left.d k k ., 1970\right)$.

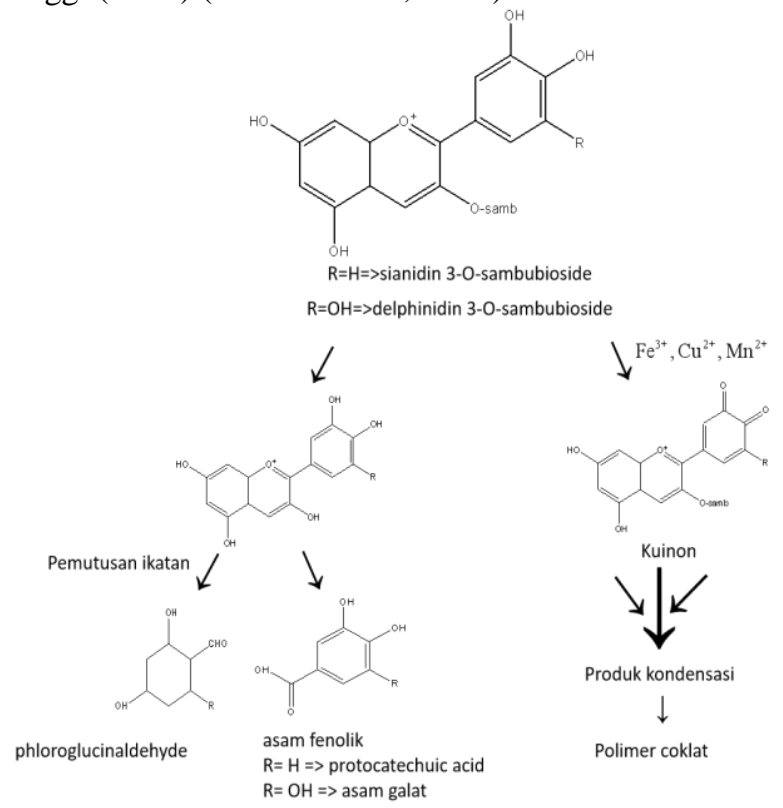

Gambar 2. Mekanisme degradasi antosianin

Mekanisme degradasi antosianin yang dimediasi oleh aldehid dan turunannya telah dilakukan oleh Dallas et al. (1996) dan Debick-Pospsil et al. (1983). Sinela et al. (2017) meneliti efek phloroglucinaldehyde dan pengaruhnya terhadap degradasi sianidin 3-Osambubioside. Penelitian ini juga menguji efek produk pada degradasi antosianin dan interaksi dianatar kedua antosianin. Berdasarkan pada senyawa fenolik, degradasi antosianin dapat dicegah atau ditingkatkan menjadi lebih panjang atau lebih pendek. Asam galat mencegah degradasi delphinidin 3-O-sambubioside. Hasil penelitian menyimpulkan baik sianidin 3-Osambubioside maupun delphinidin 3-O-sambubioside mempengaruhi degradasi antosianin yang lain.

\section{Model dari Optimasi Proses UAE}

Kadar antosianin dari kelopak bunga rosella di optimasi dengan model analisis Box Bohnken Design (BBD), variabel independen : suhu ekstraksi $\left(50-60^{\circ} \mathrm{C}\right)$, waktu ekstraksi (15-25 menit) dan Rasio (15-30 ml/g). Setiap percobaan dalam BBD dieksekusi dalam rangkap $3(\mathrm{n}=3)$. Variabel berubah dan tetap didapatkan dari Design Expert ditunjukkan pada tabel 3. Hasil percobaan untuk kadar total antosianin (aktual dan prediksi) ditunjukkan tabel 3. Hasil percobaan kadar total antosianin pada ekstrak kelopak bunga rosella ungu bervariasi dari 52,32 sampai 205,40 ppm. Persamaan 1 merupakan persamaan aktual yang diperlukan untuk mengetahui kadar antosianin prediksi. Berikut ini persamaan polinomial orde kedua digunakan untuk menyatakan hasil kadar antosianin sebagai fungsi dari variabel independen:

$298,9+27,23475 X_{1}-1,594 X_{2}-77,68583 X_{3-}$ $0,36785 \mathrm{X}_{1}^{2}+0,03295 \mathrm{X}_{2}^{2}+0,53829 \mathrm{X}_{3}^{2}-$

$0,0974 X_{1} * X_{2}+0,68473 X_{1} * X_{3}+0,4488 X_{2} * X_{3}$

dimana, $X_{1}=$ Temperature; $X_{2}=$ waktu; dan $X_{3}=$ rasio.

Waktu dan temperatur ekstraksi dalam menghasilkan ekstrak kelopak bunga rosella menggunakan metode UAE merupakan variabel yang berpengaruh terhadap kadar antosianin. Hasil optimasi gambar 3 menunjukkan bahwa peningkatan waktu ekstraksi menyebabkan kadar antosianin meningkat, namun saat mencapai titik optimum respon kadar antosianin menurun. Kondisi optimum untuk mendapatkan kadar antosianin optimum 206,996 ppm pada waktu ekstraksi 15 menit, rasio pelarut dan sampel $15 \mathrm{ml} / \mathrm{gr}$ dan temperatur ekstraksi $50^{\circ} \mathrm{C}$. Antosianin merupakan senyawa yang sensitif terhadap panas sehingga semakin lama waktu ekstraksi maka antosianin akan terdegradasi (He $d k k$., 2016). Selain waktu ekstraksi, penggunaan temperatur yang tinggi selama ekstraksi mengakibatkan degradasi antosianin dan penurunan kadar antosianin (Blackhall, Berry, Davies, \& Walls, 2018). 


\section{TEKNIK, 40 (2), 2019, 119}

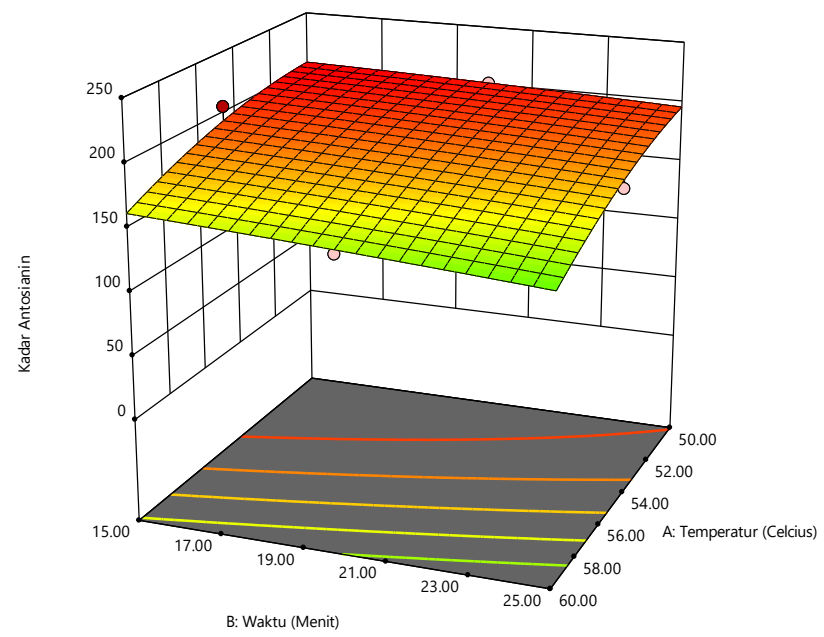

Gambar 3. Grafik pengaruh Waktu dan Temperatur ekstraksi terhadap kadar antosianin

Tabel 2 menunjukkan bahwa hasil ekstraksi total antosianin dipengaruhi secara signifikan oleh rasio pelarut dan sampel karena hasil dari nilai $P<0,01$ sehingga rasio pelarut dan sampel (X3) sangat signifikan dibandingkan dengan suhu (X1) dan waktu (X2). Interaksi X1X2 tidak signifikan $(P>0,05)$ sedangkan X1X3 dan X2X3 signifikan pada $P<0,05$. Istilah kuadrat $\mathrm{X} 3^{2}$ sangat signifikan pada $P<0,01$ diikuti oleh $\mathrm{X} 1^{2}$ dan $\mathrm{X} 2^{2}$ yang tidak signifikan pada $P>0,05$.

Tabel 2. Analisis ANOVA dari respon surface model kuadratik untuk optimasi antosianin dari kelopak bunga rosella

\begin{tabular}{llllll}
\hline Sumber & $\begin{array}{l}\text { Sum of } \\
\text { squares }\end{array}$ & df & $\begin{array}{l}\text { Mean } \\
\text { Square }\end{array}$ & $\begin{array}{l}\text { F- } \\
\text { Value }\end{array}$ & $\begin{array}{l}\text { P- } \\
\text { Value }\end{array}$ \\
\hline Model & 34909,26 & 9 & 3878,81 & 16,49 & 0,0006 \\
X1 & 10,56 & 1 & 10,56 & 0,045 & 0,8382 \\
X2 & 232,31 & 1 & 232,31 & 0,99 & 0,3534 \\
X3 & 24160,42 & 1 & 24160,42 & 102,73 & 0,0001 \\
X1X2 & 23,72 & 1 & 23,72 & 0,10 & 0,7601 \\
X1X3 & 2637,34 & 1 & 2637,34 & 11,21 & 0,0123 \\
X2X3 & 2370,23 & 1 & 2370,23 & 10,08 & 0,0156 \\
X1 & 706,39 & 1 & 706,39 & 3,00 & 0,1267 \\
X2 & 36,21 & 1 & 36,21 & 0,15 & 0,7064 \\
X3 $^{2}$ & 4877,39 & 1 & 4877,39 & 20,74 & 0,0026 \\
Lack of fit & 1646,24 & 3 & 548,75 & & \\
Pure Error & 0,000 & 4 & 0.000 & & \\
& & & & & \\
\hline
\end{tabular}

Hasil ANOVA dari hasil kelayakan model dan untuk mendapatkan model analisis, nilai $\mathrm{R}^{2}$, nilai $\mathrm{F}$, nilai $P$. Berdasarkan hasil Analisis Varians (ANOVA) design expert untuk respon kadar antosianin menghasilkan nilai $P$ sebesar 0,01 maka model matematis ini dapat diterima karena memiliki pengaruh yang signifikan. Menurut $\mathrm{He}$ et al. (2016) model matematis memiliki pengaruh yang signifikan jika nilai $P$ kurang dari 0,05 sedangkan tidak memiliki pengaruh signifikan jika nilai $P$ lebih dari 0,05 . Nilai $\mathrm{R}^{2}$ didapatkan sebesar $0,98 \%$ sehingga $0,02 \%$ merupakan faktor lain yang tidak termasuk pada model optimasi.

\section{Hasil Validasi Prediksi Model \\ Optimasi kondisi ekstraksi antosianin} menggunakan Box Bohnken Design ditunjukkan pada tabel 3. Hal ini diperlukan analisis kelayakan untuk membandingkan kadar antosianin aktual dan prediksi. Analisis kelayakan model dalam menggambarkan data empiris dengan validasi. Validasi ini dilakukan menggunakan nilai prediksi yang diperoleh dari persamaan 1 dengan nilai aktual dari hasil penelitian. Hasil validasi ditunjukkan pada gambar perbandingan nilai prediksi dan nilai aktual untuk respon kadar antosianin.

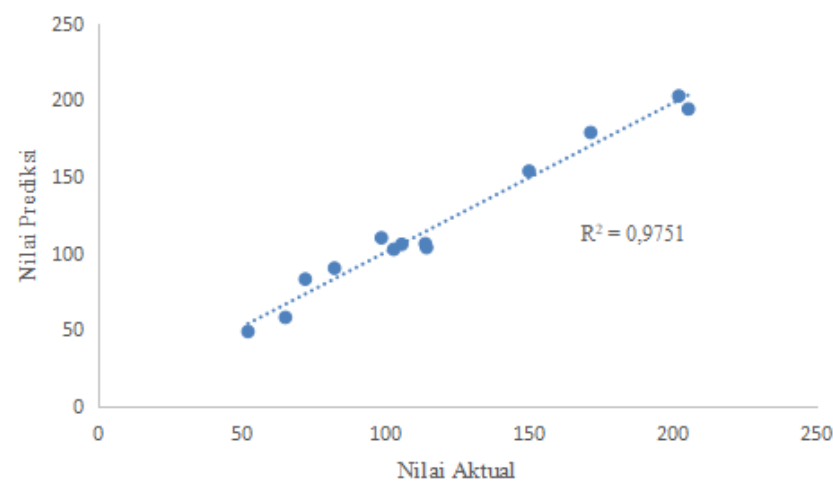

Gambar 4. Perbandingan nilai prediksi dan aktual untuk respon kadar antosianin

Perbandingan nilai prediksi dan aktual untuk respon kadar antosianin ditunjukkan pada gambar 4 . Analisis kelayakan hasil nilai prediksi dan aktual diperoleh nilai $\mathrm{R}^{2}$ sebesar $98 \%$. Hal ini menunjukkan bahwa nilai prediksi dan aktual mempunyai pengaruh yang besar sehingga memiliki kecocokan model yang sangat baik karena $\mathrm{R}^{2}$ mendekati 1 .

\section{Kesimpulan}

Kondisi optimum untuk mendapatkan senyawa bioaktif antosianin dari rosella menggunakan desain Box Bohnken Design berhasil dioptimalkan. Analisis kelayakan nilai prediksi dan aktual mempunyai kecocokan model yang sangat baik. Kondisi optimum waktu ekstraksi, rasio pelarut dan sampel, temperatur ekstraksi untuk menghasilkan ekstraksi maksimum senyawa antosianin. Parameter ekstraksi yang optimal adalah waktu ekstraksi 15 menit, rasio sampel dan pelarut $15 \mathrm{gr} / \mathrm{ml}$ dan temperatur ekstraksi $50^{\circ} \mathrm{C}$. 


\section{TEKNIK, 40 (2), 2019, 120}

\section{Daftar Pustaka}

Bezerra, M. A., Santelli, R. E., Oliveira, E. P., Villar, L. S., Escaleira, L. A. (2008). Response surface methodology (RSM) as a tool for optimization in analytical chemistry. Talanta, 76, 965-977. https://doi.org/10.1016/j.talanta.2008.05.019

Blackhall, M. L., Berry, R., Davies, N. W., Walls, J. T. (2018). Optimized extraction of anthocyanins from Reid Fruits' Prunus avium "Lapins" cherries. Food Chemistry, 256, 280-285. https://doi.org/10.1016/j.foodchem.2018.02.137

Boer, L. de. (2013). Health safety issues of synthetic food colorants. Advances in Biochemical Engineering, 143, 51-89. https://doi.org/10.1016/j.yrtph.2015.09.026

Castañeda-Ovando, A., Pacheco-Hernández, M. de L., Páez-Hernández, M. E., Rodríguez, J. A., GalánVidal, C. A. (2009). Chemical studies of anthocyanins: A review. Food Chemistry, 113(4), 859-871.

https://doi.org/10.1016/j.foodchem.2008.09.001

Chavan, R. S., Avhad, D. N., Rathod, V. K. (2015). Optimization of Aqueous Two-Phase Extraction of Protease Produced from Bacillus licheniformis NCIM 2042 Using Response Surface Methodology. Separation Science and Technology , 50(1), 45-55. https://doi.org/10.1080/01496395.2014.948963

Chen, W., Müller, D., Richling, E., Wink, M. (2013). Anthocyanin-rich purple wheat prolongs the life span of Caenorhabditis elegans probably by activating the DAF-16/FOXO transcription factor. Journal of Agricultural and Food Chemistry, 61(12), 3047-3053. https://doi.org/10.1021/jf3054643

Cissé, M., Bohuon, P., Sambe, F., Kane, C., Sakho, M., Dornier, M. (2012). Aqueous extraction of anthocyanins from Hibiscus sabdariffa: Experimental kinetics and modeling. Journal of Food Engineering, 109(1), 16-21. https://doi.org/10.1016/j.jfoodeng.2011.10.012

Corbin, C., Fidel, T., Leclerc, E. A., Barakzoy, E., Sagot, N., Falguiéres, A., Hano, C. (2015). Development and validation of an efficient ultrasound assisted extraction of phenolic compounds from flax (Linum usitatissimum L.) seeds. Ultrasonics Sonochemistry, 26, 176-185. https://doi.org/10.1016/j.ultsonch.2015.02.008

Cowan, M. M. (1999). Plant products as antimicrobial agents. Clinical Microbiology Reviews, 12(4), 564-582. https://doi.org/10.1128/CMR.12.4.564

Dai, J., Mumper, R. J. (2010). Plant phenolics: Extraction, analysis and their antioxidant and anticancer properties. Molecules, 15(10), 7313-
7352. https://doi.org/10.3390/molecules15107313

Dallas, C., Ricada-da-Silva, J., Laureano, O. (1996). Products formed in model wine solution involving anthocyanins, procyanidin B2, and acetaldehyde. Journal of agricultural and food chemistry, 44(8), 2402-2407.

Debick-Pospsil, J., Lovric, T., Trinajstic, N., Sabjic, A. (1983). Anthocyanin Degradation in the Presence of Furfural and 5-Hydroxymethylfurfural. Journal of food science, 48(2), 411-416.

Elias, R. J., Andersen, M. L., Skibsted, L. H., Waterhouse, A. L. (2009). Key factors affecting radical formation in wine studied by spin trapping and EPR spectroscopy. American Journal of Enology and Viticulture, 60(4), 471-476.

Eiman, H. A. R. E., Elhadi, M. A., Nizar, S. (2014). Standardization of Roselle (Hibiscus sabdariffa L.) Calyx cultivated in Sudan. Journal of Medicinal Plants Research, 8(4), 217-222. https://doi.org/10.5897/JMPR2013.4448

He, B., Zhang, L., Yue, X., Liang, J., Jiang, J., Gao, X., Yue, P. (2016). Optimization of ultrasoundassisted extraction of phenolic compounds and anthocyanins from blueberry ( Vaccinium ashei ) wine pomace. Food Chemistry, 204, 70-76. https://doi.org/10.1016/j.foodchem.2016.02.094

Hrazdina, G., Borzell, A., Robinson, W. (1970). Studies on the Stability of the Anthocyanidin-3, 5Digucosides. American Journal of Enology and Viticulture, 21(4), 201-204.

Hussein, R. M., Shahein, Y. E., Hakim, A. E. El, Awad, H. M. (2010). Biochemical and molecular characterization of three colored types of roselle (Hibiscus sabdariffa L.). Journal of American Science, 11(6), 726-733.

Inggrid, H. M., Jaka, Santoso, H. (2017). Natural red dyes extraction on roselle petals. IOP Science, 1$7 . \quad$ https://doi.org/10.1088/1757899X/162/1/012029

Ismail, A., Ikram, E. H. K., Nazri, H. S. M. (2008). Roselle (Hibiscus sabdariffa L.) Seeds Nutritional Composition, Protein Quality and Health Benefits. Food, 2(1), 1-16.

Lee, J., Durst, R. W., Wrolstad, R. E. (2005). Determination of total monomeric anthocyanin pigment content of fruit juices, beverages, natural colorants, and wines by the $\mathrm{pH}$ differential method: Collaborative study. Journal of AOAC International, $\quad 88(5), \quad$ 1269-1278. https://doi.org/10.5555/jaoi.2005.88.5.1269

Li, H., Guo, A., Wang, H. (2008). Mechanisms of oxidative browning of wine. Food Chemistry, 108(1), 1-13.

Maran, J. P. (2017). Ultrasound assisted extraction of bioactive compounds from Nephelium lappaceum 


\section{TEKNIK, 40 (2), 2019, 121}

L . fruit peel using central composite face centered response surface design. Arabian Journal of Chemistry,

10 ,

S1145-S1157.

https://doi.org/10.1016/j.arabjc.2013.02.007

Newsome, A. G., Culver, C. A., Breemen, R. B. Van. (2014). Nature' s Palette: The Search for Natural Blue Colorants. Journal of Agricultural and Food Chemistry, 62, 28, 6498-6511.

Pandey, A., Tripathi, S. (2014). Concept of standardization, extraction and pre phytochemical screening strategies for herbal drug. Journal of Pharmacognosy and Phytochemistry JPP, 115(25), 115-119. https://doi.org/10.1037/02787393.6.2.107

Piyarat, K., Walaisiri, M. Pornpen, W., I. (2014). Comparison of stability of red colorants from natural sources, roselle and lac in micelles. International Food Research Journal, 21(1), 325330.

Sinela, A. M., Mertz, C., Achir, N., Rawat, N., Vidot, K., Fulcrand, H., Dornier, M. (2017). Exploration of reaction mechanisms of anthocyanin degradation in a roselle extract through kinetic studies on formulated model media. Food Chemistry, 235:67-75. .http://dx.doi.org/10.1016/j.foodchem.2017.05.027

Solymosi, K., Latruffe, N., Morant-Manceau, A., Schoefs, B. (2015). Food colour additives of natural origin. Colour Additives for Foods and Beverages, 4-34. https://doi.org/10.1016/B978-178242-011-8.00001-5

Triyastuti, M. S., Kumoro, A. C., Djaeni, M. (2017). Physical properties evaluation of roselle extractegg white mixture under various drying temperatures. AIP Conference Proceedings, 1823. https://doi.org/10.1063/1.4978116

Vinha, A. F., Rodrigues, F., Nunes, M. A., Oliveira, M. B. P. P. (2018). Natural pigments and colorants in foods and beverages. Polyphenols: Properties, Recovery, and Applications. Elsevier Inc. https://doi.org/10.1016/B978-0-12-8135723.00011-7. 